\title{
Psychological Impact of Online Learning to EFL Students Under COVID-19 Pandemic
}

\author{
Yosefina Helenora Jem ${ }^{1}$, Fransiskus Jemadi², Yustus Sentus Halum ${ }^{3}$ \\ Universitas Katolik Indonesia Santu Paulus Ruteng ${ }^{123}$ \\ \{jemyosefina@gmail.com\}
}

\begin{abstract}
This writing is intended to investigate the impact of online learning under COVID-19 pandemic to EFL students' psychology. It specially concerns on EFL students' level of anxiety in online learning during this pandemic. A survey had been conducted to assess one hundred EFL students' level of anxiety by using Zung Self-Rating Anxiety Scale, which consists of twenty items as the questionnaire. Each item of the collected questionnaire respond was calculated to find the frequency and mean. After having the mean of each item, the researchers find the mean of all items to determine students' level of anxiety by using likert scale. The result indicates that, students' level of anxiety is low $(2,065)$. Regarding to the result, it can be concluded that having EFL online class under COVID-19 pandemic does not afford negative impact on students' psychology.
\end{abstract}

Keywords: anxiety, online learning, EFL students, COVID-19 pandemic

\section{Introduction}

Online learning system has been applied for an academic year in Indonesia. It is due to the rapid grow and spread of COVID-19. The implementation of online learning system is expected to facilitate learning activities like in conventional system (face-to-face classroom meeting). Simply, online learning is defined as the use of internet and technological devices in teaching and learning process. Online learning or e-learning is described as the use of internet and new technological devices in improving learning quality by providing huge access to facilities and service as well as distant exchanges and collaboration [1]. It is the use of information and communication technology in various educational processes to support and increase learning quality in higher educational institution, and ecompasses the use of information and communication technology as a supplement to conventional classroom, online learning or mixing the two modes [2]. Regarding to those definitions stated, it can be said that there are two main components in running online learning, namely technological devices (such as computer) and internet connection. Without the presence of those two components, the online learning cannot be carried out.

Furthermore, the implementation of online learning under the COVID-19 pandemic is expected to be the solution in this current situation. Through online learning, teacher and students can run teaching and learning process like in conventional classroom. The teachers can share material, doing communication, giving task and examination as well as giving feedback by using number of applications in internet. By using the same applications, students can involve in classroom discussion, response to the task, completing the examination and receiving feedbacks from teacher. This learning system allows teacher and students to teach and study 
from anywhere and anytime [3]. They do not have to be in the same place and are not required to travel across town.

Moreover, online learning is saving significant amount of money and time [4]. Since the online learning can be carried out from anywhere and anytime, teacher and students are free from paying some fees like transportation and lodging. They do not have to spend money for copying the material. They also do not need to spend much time in travelling from home to school and vice versa [5]. Despite the fact that online learning is advantages for some reasons, it also has weaknesses. It destructs social interaction of teacher-students and student-students. It is not an easy to keep in touch with teacher [4]. Students find difficulties to get quick response from teacher. Teachers are difficult to control their students and having their full attention in classroom discussion because their students are easy to be disturbed by other things. It is tough for teacher to make sure that students really understand the topic of being learnt. Besides, there is no guarantee that students 'works (completing assignment or examination) refers to their original works.

Another obstacle is technical problem. It refers to facilities to support the online learning. Not all the students have computer or android to support them in following online learning. An expensive internet quota and unstable internet connection are other stumbling blocks in applying online learning. In addition, there are still number of educators who still find problems in using online learning platforms, such as Google Classroom and Zoom meeting [6]. This causes online learning is running by using very limited application and just for sending assignment from teacher to students without having communication with students or responsibility to give feedback on students 'assignment. Thus, if the online learning still carries out the same barriers will take place during the implementation of this learning system. This circumstance may disturb students 'psychological condition in which they will experience stress, anxiety or even depression.

Research on the impact of online learning towards learner's psychology have been conducted by many researchers. One research reports that online learning psychologically impactful to higher education students where $29 \%$ students are in above normal of depression level, $70 \%$ students are having anxiety level above normal, and $46 \%$ students experience stress level above normal [6]. In line with this, Wahyu and Rostome [7] reported that students in Inkes Helvetia Medan stress in joining online learning where $48.9 \%$ of students experienced light stress, $42.6 \%$ experienced moderate stress and $4 \%$ experienced severe stress. Supporting Wahyu and Rosmote, another study emphasized that $3 \%$ of the Vocational student are having stress level in extremely severe categories, $13 \%$ in severe categories, $8 \%$ in moderate categories, $24 \%$ in mild categories, and $52 \%$ in normal categories [8].

Those previous research examine students 'psychology as the impact of running online learning. They concern on Vocational students and undergraduate health students. However, the studies on the impact of online learning to EFL student's psychology are still difficult to be found even though, they also carry out online learning. This is because all students involve in online learning, including English College students at Universitas Katolik Indonesia Santu Paulus Ruteng. The English college students at university are prepared to be English teacher in the future. It is really significant for them to study without having stress, anxiety or other psychological pressure under this COVID-19 pandemic. This is because they need to master English skills and components and other courses as their provision to become an English teacher. For that reason, this study has been conducted to measure English college students 'level of anxiety in taking courses under COVID-19 pandemic.

This study is significant for investigating how is the impact of online learning towards EFL students'psychological condition. The result of this study is essential for English lecturers and 
or teachers in general as a source of an accurate information related to students ' anxiety in taking online learning. Therefore, the English lecturers and or teachers are able to design or manage their online class.

\section{Research Methods}

This study has been conducted quantitatively. This is because this study wants to examine anxiety level of English college students at Universitas Katolik Indonesia Santu Paulus Ruteng. In collecting the data, the researchers conducted an online survey by adapted Zung Self-Rating Anxiety Scale as the questionnaire. The questionnaire consists of twenty items and were distributed to 100 English students as the respondents. Those respondents are choosen by random sampling technique. The participants are asked to respond using Likert Scale 1= seldom, $2=$ sometimes, $3=$ often and $4=$ always

The collected data then analysed by the researchers to find the frequency and mean of each item of the questionnaire. After having the mean of each item, the mean for all item are determined to examine students'level of anxiety. In examining students'level of anxiety, the researchers used Likert Scale as shown in the following table:

Table 1. Four Categories of Likert Scale

\begin{tabular}{lcc}
\hline No & Interval & Category \\
\hline 1 & $1-1.75$ & Very Low \\
2 & $1.76-2.50$ & Low \\
3 & $2.51-3.25$ & High \\
4 & $3.26-4$ & Very High \\
\hline
\end{tabular}

\section{Results and Discussion}

This part presents the results and the discussion of the research.

\subsection{Results}

After getting the collected data, the frequency and the mean of the questionnaire are calculated and the reseults are presented in the following table.

Table 2. The Result of Questionnaire

\begin{tabular}{lcccccc}
\hline \multicolumn{1}{c}{ Statement } & Seldom & Sometimes & Often & Always & Mean & Category \\
\hline $\begin{array}{l}\text { I feel more nervous and anxious in } \\
\text { online class than in traditional class. }\end{array}$ & 19 & 63 & 13 & 5 & 2.04 & Low \\
$\begin{array}{l}\text { I feel afraid for no reason at all in } \\
\text { online class }\end{array}$ & 35 & 46 & 14 & 5 & 1.89 & Low \\
$\begin{array}{l}\text { I get upset easily or feel panicky in } \\
\text { online class }\end{array}$ & 22 & 50 & 16 & 12 & 2.18 & Low \\
$\begin{array}{l}\text { I feel like I'm falling apart and going } \\
\text { to pieces in online class. }\end{array}$ & 39 & 45 & 13 & 3 & 1.80 & Low \\
I feel that everything is all right and & 19 & 40 & 28 & 13 & 2.35 & Low
\end{tabular}

nothing bad will happen in online

class 


\begin{tabular}{|c|c|c|c|c|c|c|}
\hline $\begin{array}{l}\text { My arms and legs shake and tremble } \\
\text { in online class. }\end{array}$ & 47 & 30 & 19 & 4 & 1.80 & Low \\
\hline $\begin{array}{l}\text { I am bothered by headaches neck and } \\
\text { back pain in online class. }\end{array}$ & 35 & 40 & 21 & 4 & 1.94 & Low \\
\hline $\begin{array}{l}\text { I feel weak and get tired easily in } \\
\text { online class }\end{array}$ & 25 & 39 & 31 & 5 & 2.16 & Low \\
\hline $\begin{array}{l}\text { I feel calm and can sit still easily in } \\
\text { online class. }\end{array}$ & 12 & 46 & 27 & 15 & 2.45 & Low \\
\hline $\begin{array}{l}\text { I can feel my heart beating fast in } \\
\text { online class. }\end{array}$ & 19 & 48 & 26 & 7 & 2.21 & Low \\
\hline $\begin{array}{l}\text { I am bothered by dizzy spells in } \\
\text { online class. }\end{array}$ & 33 & 45 & 17 & 5 & 1.94 & Low \\
\hline $\begin{array}{l}\text { I have fainting spells or feel like it in } \\
\text { online class. }\end{array}$ & 59 & 32 & 8 & 1 & 1.51 & $\begin{array}{l}\text { Very } \\
\text { Low }\end{array}$ \\
\hline $\begin{array}{l}\text { I can breathe in and out easily in } \\
\text { online class. }\end{array}$ & 14 & 21 & 16 & 49 & 3.00 & High \\
\hline $\begin{array}{l}\text { I get feelings of numbness and } \\
\text { tingling in my fingers \&amp; toes in } \\
\text { online class. }\end{array}$ & 49 & 27 & 21 & 3 & 1.78 & Low \\
\hline $\begin{array}{l}\text { I am bothered by stomach aches or } \\
\text { indigestion in online class. }\end{array}$ & 42 & 38 & 12 & 8 & 1.86 & Low \\
\hline $\begin{array}{l}\text { I have to empty my bladder } 3 \text { in } \\
\text { online class. }\end{array}$ & 36 & 35 & 18 & 11 & 2.04 & Low \\
\hline $\begin{array}{l}\text { My hands are usually dry and warm in } \\
\text { online class }\end{array}$ & 27 & 44 & 16 & 13 & 2.15 & Low \\
\hline $\begin{array}{l}\text { My face gets hot and blushes in online } \\
\text { class. }\end{array}$ & 40 & 41 & 15 & 4 & 1.83 & Low \\
\hline $\begin{array}{l}\text { I fall asleep easily and get a good } \\
\text { night's rest in online class. }\end{array}$ & 22 & 32 & 27 & 19 & 2.43 & Low \\
\hline I have nightmares in online class. & 29 & 53 & 13 & 5 & 1.94 & Low \\
\hline Mean & & & & & 2.06 & Low \\
\hline
\end{tabular}

The result of the questionnaire above can be figured out in the following figure:

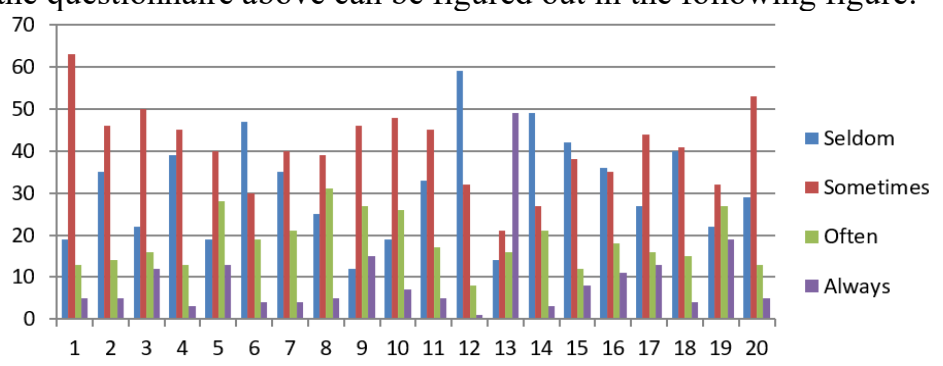

Fig 1. The Frequency of Students` Responds

\subsection{Discussion}

From the data in table 1 and figure 1 and supporting by the result of calculation of the mean, it can be said that English college students at Universitas Katolik Indonesia Santu Paulus Ruteng are enjoying the online learning process under the COVID-19 pandemic. The first questionnaire item is asking students' feeling whether they feel more nervous and anxious than usual or not. From 100 respondents 19 persons said that they seldom have that kind of feeling, 63 persons sometimes feel more nervous and anxious, 13 person often experience feeling of more nervous and anxious than before and only 5 persons who always feel more nervous and anxious in following online class under COVID-19 pandemic. Based on the respondents answer, it is calculated that the mean for this item is 2.04 . It means that students' level of feeling 
nervous and anxious is low. This result indicates that students do not feel nervous and anxious in following online class within this pandemic.

Moreover, the second item confirms that 35 subjects seldom feel afraid for no reason, 46 subjects sometimes feel afraid for no reason, 14 subjects are often afraid for no reason, while 5 subjects always feel afraid for no reason. From the result, the mean of this item is 1.89 which means that students' feeling afraid for no reason in following online class is in low level. It emphasizes that, in online class there is nothing to be afraid of by students. Everyhing is done through the same process as in conventional class. The difference is only in the method in which that in conventional class they have face-to-face classroom meeting, while in online learning they use techological media and the internet to join the class.

For the third item, there are 22 students who say that they seldom get upset easily of feel panicky in joining online class. 50 students mention that they sometimes easily to get upset, 16 students answer they often feel panicky and only 12 students who always feel panicky. The mean for this item is 2.18 and it is categorized in low level. The result of this item informs that English College students at Universitas Katolik Indonesia Santu Paulus Ruteng do not feel panicky or easy to be upset in involving in online class.

The next item indicates that students' level of anxiety is low in which the mean is 1.80 . In this item, 39 respondents answer seldom feel like falling apart and going to pieces, 45 respondents answers sometimes feel like falling apart and going to pieces, 13 respondents often feel like falling apart and going to pieces and just 3 respondents who always feel like falling apart and going to pieces. This result significantly reports that students do not feel underpressure when online class is carried out.

Furthermore, in responding item number 5, 19 subjects inform that they seldom feel that everything is all right and nothing bad will happen. 40 subjects say they sometimes feel that everything is all right and nothing bad will happen, 28 subjects answer they often feel that everything is all right and nothing bad will happen and 13 students say that they always feel that everything is all right and nothing bad will happen. The mean for this item is 2.35 which means low. In responding this item, students are not optimistic that in online learning everthing will run well. Their response for this item is contradictory compared to the previous responds for the first until fourth items. It means that even the students do not feel more nervous and anxiety than usual/feel afraid for no reason/get upset easily or panicky/feel like falling apart and going to pieces, they still realize that something bad will happen in carrying out online learning. They feel that, some obstacles might involve when they are in online class.

Besides, item numbers $6,7,8,14,15,16,17$ and 18 which asked students' phsycal condition confirms that having online classes under this pandemic do not have distressing impacts toward students' physical condition. It is proved by the mean of each item in which they are categorized in low level. Different condition may occur, if learners feel more nervous, anxious and panicky than usual. The learners can be disturbed by headache, neck and backpain. They are easy to experience weakness and tiring. However, the students do not face those psychical condition due to the stabil pshychological condition. Regarding to the students respond for those items, it can be said that there is an intimate relationship between psychological and physical conditions. A healthy and stable psychological condition will cause someone's physical condition better. Thus, in the healthy body, there is a strong soul. It enables learners to be able to join and understand the material in online classes. It encourages students ${ }^{6}$ to be enthusistic in attending online courses.

In responding item number 9, 12 subjects answer they seldom feel calm and can sit still easily. 46 students answer sometimes they feel calm and can sit still easily, 27 students answer they often feel calm and can sit still easily and 15 students answer they always feel calm and 
can sit still easily. The mean for this item is 2.45 and categorized as low level. This result is in line with the result of item number 5 . Both items (items 5 and 9) confirms that students feel worry while having online classes. They cannot stay calm because in online learning some obstacles migh occur.

In contrast with item 5 and 9, item number 10 confirms that students are still able to breath normally. From 100 subjects, 19 students mention they seldom feel their heart beating fast, 48 students sometimes feel their heart beating fast, 26 students often feel their heart beating fast and 7 students always feel their heart beating fast. The mean of this item (2.21) is categorized as low. It means that the students really enjoy the online learning class.

Another interesting result is coming from item number 19 and 20. The item number 19 asked students whether it is easy or not for them to fall asleep, whether they have good night rest or not. From 100 subjects, 22 subjects answer they seldom fall asleep easily and get good night rest. 32 subjects say they are sometimes easy to fall asleep and get good night's rest. 27 subjects often fall asleep easily and get good nigt's rest, while the rest (19 subjects) are always easy to fall asleep and get good nigt's rest. Those response were calculated to find the mean. The result of mean calculation is 2.43 and categorized in low level. Based on that result, the researchers assume that the online learning might be not really easy for students. There must be problem faced by students which annoy their mind. That's why as human being, it is difficult to fall asleep and have a good night's rest while having something heavy in mind.

The last is students' response for item number 20. The result of questionnaire says that 29 students seldom have nightmare; 53 students sometimes have nightmares; 13 students often have nightmares, while 5 students always have nightmare. The mean of this item is 1.94 and is in low level. It means that the online learning system donot make students experience nightmares even they face difficulty to fall asleep or to get good night's rest. Regarding to the students' response of each item of the questionnaire, it can be mentioned that there is inconsistency from students in answering or responding each item of the questionnaire. Some item results are condratictory to other items. For instance, in answering item numbers 1, 2, 3, and 4 most students mention that just some of the time they feel more nervous and anxious than usual or feel afraid for no reason or get upset easily and panicky or feel like falling apart and going to pieces. Those four responses in line with the response for item number 13 in which that the students confirms that they are able to breath normally even the class is done through online system.

Nevertheless, those are in contrast with students' response for item numbers 5 and 9 . The students feel that everything is not all right and something bad will happen in online learning. That's why for item number 9, they mention that it is difficult for them to stay calm and sit or pretending that everything is all right. Because the students experience that psychological condition, they then find difficulties to fall asleep or get a good night's rest as they confirm through item number 19 . However, those bad or negative psychological conditions (items number 5,9 , and 18) experienced by students do not make students have nightmares (item number 20).

Even though, there are data which are contrastive, the mean result for the whole data can be obtained. It was calculated that the mean for the whole data is 2.065 . It indicates that students ${ }^{6}$ level of anxiety is low. This result is in line with and mirrors the previous studies, where the researchers mentioned that only small numbers of students (4\% and $13 \%)$ who experienced severe stress level [7\&8]. In addition, this study result rejects the study result where it is mentioned that $70 \%$ higher education students are having anxiety level above normal [6]. 


\section{Conclusion}

\subsection{Conclusion}

The online learning system has been carried out by students of English Study Program at UNIKA St. Paulus. They involved in this learning system due to the rapid grow of COVID-19 pandemic. This learning system is carried out to replace the traditional learning system. Involving in online learning affects student's psychological condition. They may feel stress, having anxiety, depression or frustration. Fortunately, the students of English study program at UNIKA St. Paulus Ruteng did not experience that negative psychological condition. The study result describes that the student's level of anxiety is in low category. It means that the students really enjoy the process of online learning.

\subsection{Suggestion}

Based on the result and discussion of the study, the researchers want to offer suggestions for the following people. The first is further researchers. They are suggested to do further investigation on the psychological impact of online learning to students especially students in remote area with limited internet access. They could compare whether there are significant differences in psychological conditions of online learning between students in the city and remote area. The second is the students. Due to some contradiction occur in questionnaire result, they are suggested to be more aware in giving or answering the questionnaire. They need to consider the sound of each statement and really reflect it to their experience. Their answers are mean a lot to the researchers. They are also advised to be able to manage their psychological condition to be successful in following online learning courses.

\section{References}

[1] European Commission: The eLearning Action Plan: Designing tomorrow's education. http://www.elearningeuropa.info. (2001)

[2] OECD: E-learning in tertiary education [Online]. Available at http://www.cumex.org. (2005)

[3] Nagrale, P: Advantages and disadvantages of distance education. https://surejob.in/advantagesanddisadvantages-of-distance-education.html. (2013)

[4] Sadeghi, M: A shift from classroom to distance learning: advantages and limitations. International Journal of Research in English Education, Vol. 4(1), pp. 80-88 (2019)

[5] Arkorful, Valentina \& Nelly Abaidoo: The Role of E-Learning, The Advantages and Disadvantages of Its Adoption in Higher Education. International Journal of Education and Research, Vol. 2 (12), pp. 387-410 (2014)

[6] Maulana, H. A: Psychological Impact of Online Learning during the COVID-19 Pandemic: A Case Study on Vocational Higher Education. Indonesian Journal of Learning Education and Counseling, 3(2), 130-139 (2021)

[7] Wahyu, A., \& Simanullang, R. H.: Student Stress Due to Online Learning During the Covid-19 Pandemic. Jurnal Aisyah: Jurnal Ilmu Kesehatan, 5(2), 153-157 (2020)

[8] Maulana, H. A., \& Iswari, R. D.:Analisis Tingkat Stres Mahasiswa Terhadap Pembelajaran Daring Pada Mata Kuliah Statistik Bisnis Di Pendidikan Vokasi. Khazanah Pendidikan, 14(1) (2020) 